\title{
BEHAVIOUR OF HIGH-PERFORMANCE CONCRETE BEAMS AS AFFECTED BY BONDED PART AND RIB GEOMETRY OF MAIN STEEL REINFORCEMENT
}

\author{
Aly Abdel-Zaher ELsayed ;Hosny M . Soghair ; \\ Mohamed M. Rashwan \\ Civil Engineering Department, Faculty of Engineering, Assiut University, \\ Assiut, Egypt.
}

\section{Ali Mohamed Abdallah Abou-Zied \\ Engineer in the general Authority of Educational Buildings Sohag, Egypt (Ph.D Student)}

(Received December 8, 2009 Accepted January 3, 2010).

\begin{abstract}
The need of high-performance concrete is increased in the recent years. Also using steel of high grade and maximize the benefit of using these material become necessary. So, different ribs are used for enhancing the bond strength between steel reinforcement and high-performance concrete. There is little information in the available literature about the bond characteristics for the different forms of rib geometry of the deformed bars and its effect on behavior of high-performance concrete beams for different relative rib area $\left(\alpha_{s b}\right)$ and development length.

The main objective of this research is to study the effect of bonded part and rib geometry of main steel bars on behavior of high-performance concrete beams, also Pattern of cracks, final mode of failure and deformation characteristics (deflection, slip, concrete strain and slope for beams) were investigated.
\end{abstract}

KEYWORDS: Bond; High performance concrete; beams; behavior; rib geometry; steel.

\section{1- INTRODUCTION}

In the last 20 years, the concrete with compressive strength exceeding to $700 \mathrm{~kg} / \mathrm{cm}^{2}$ and ranging up to $1200 \mathrm{~kg} / \mathrm{cm}^{2}$ has been achieved consistently and utilized in bridges and high rise building construction. This concrete described as high-strength concrete(HSC) . Acording to the recent CEB/FIP report, ${ }^{(1)}$ high-strength concrete is defined as : "All concrete with a compressive cylinder strength above the present existing in national codes, i.e. abou $600 \mathrm{~kg} / \mathrm{cm}^{2}$, and up to $1300 \mathrm{~kg} / \mathrm{cm}^{2}$. These include high modulus of elasticity, high density, and long-term durability . Durability of this concrete is achieved by its low permeability, resistance to chlorideiondiffusion, abrasion resistance, and resistance to other forms of chemical and physical attack. Therefore, it is logical to refer to concrete this as high-performance concrete (HPC) .

Since 1990, several studies have been conducted to investigate specifically the bond strength of reinforcement in high strength concrete. de Larrard et al. [1993] ${ }^{(2)}$ evaluated the bond strengh between high strength concrete and reinforcing bars using 
the RILEM beam test. A high strength concrete with 28-day compressive strength of $95 \mathrm{MPa}$ was used along with a normal strength concrete of $42 \mathrm{MPa}$ as control. Three different sizes of deformed bars $(10,16,25 \mathrm{~mm})$ and one smooth bar $(25 \mathrm{~mm})$ were used. Based on several preliminary tests, the RILEM recommended bond (anchorage) length of 10 times bar diameter had to be reduced to 3 times to 2.5 times bar diameter for high strength concrete to ensure bond failure rather than yielding of reinforcement. Transverse reinforcement was used in the test specimens so the lateral confinement of concrete was provided. The average bond strength along the bond length was calculated corresponding to the free end slip of the bar at 10 and $100 \mathrm{~mm}$. It was concluded that the effect of bar size on bond strength was very significant as one would expect. The increase in bond strength with high strength concrete (as compared to normal strength concrete) was approximately $80 \%$ for $10 \mathrm{~mm}$ deformed bars and $30 \%$ for $25 \mathrm{~mm}$ deformed bars. The improvement of bond is attributed to the increase in concrete tensile strength and confinement due to both concrete shrinkage and transverse reinforcement. The bond characteristics along a high-strength beam reinforcement within an interior beam-column joint panel under monotonic loading was studied by Kitayama et al. [1991] ${ }^{(3)}$. They found that the bond strength reached the maximum value for the joint constructed with high-strength concrete and steel until a diagonal shear crack occurred across the beam reinforcement. On the contrary, with lower strength concrete and steel, the bond deterioration of the joint panel was caused by yielding of the beam reinforcement. A study of anchorage of beam reinforcement within a typical high-strength concrete interior beam-column joint under load reversals was conducted by Lee et al. [1991] ${ }^{(4)}$. Based on their results, it was concluded that the design criterion of bond performance recommended by the Architectural Institute of Japan (AIJ) can not be applied to the high-strength reinforced concrete. Kaku et al. $[1992]^{(5)}$ tested 26 simply supported beams to investigate bond splitting strength of tensile reinforcement in a shear span. Test variables included concrete strength $(40,60$, $80,100 \mathrm{MPa}$ ), development length and spacing of reinforcement, amount and detail of transverse reinforcement, and two cross sections of test specimens. The test results indicated that (1) the bond splitting strength is proportional to $\sqrt{\mathrm{fc}^{\prime}}$ or, more conservatively, $\left(\mathrm{fc}^{\prime}\right)^{0.6},(2)$ the use of transverse reinforcement with supplementary ties significantly increases the bond splitting strength, (3) without transverse reinforcement, bond strength decreases with increase in development length, and (4) bond strength ratio of top bars to bottom bars increases to unity with increase of concrete strength. Based on the test results, a bond strength equation was developed which acounts for the concrete strength, the development length and spacing of reinforcement, and the amount and detail of transverse reinforcedment. The proposed equation is slightly more conservative than the recommendation of the Architectural Institute of Japan.

The effect of rib geometry for steel reinforcement on bond of normal strength concrete study by Ali M.A...(2000) ${ }^{(6)}$ Found that the final mode of failure, cracking and ultimate load and deformation for cantilever-to-column connection efective by the relative rib area $\left(\alpha_{\mathrm{sb}}\right)$ and development length. The geometry of the ribs can be expressed by the relative rib area $\alpha_{\mathrm{sb}}$ is described by Rehm ${ }^{(7)}$ as :

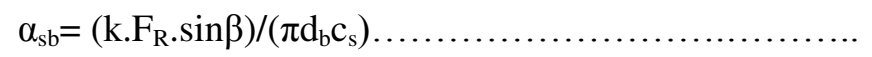

Where: $\mathrm{k}=$ number of transverse ribs around the bar perimeter, $\mathrm{db}=$ nominal diameter of bar, $F_{R}=$ area of one transverse rib, $\beta=$ angle of the rib , $c_{s}=$ distance between rib 


\section{2- EXPERIMENTAL PROGRAM}

Nine beams were tested with main steel diameters $16 \mathrm{~mm}$ and rectangular cross section equal to $12 \times 30 \mathrm{~cm}^{2}$ as shown in Fig (1). The considered span for beams were $240 \mathrm{~cm}$ for all beams. Strength of concrete $\left(f_{c}\right)$ were $900 \mathrm{~kg} / \mathrm{cm}^{2}$. The study takes into consideration the following parameters:

1. Rib geometry and its relative rib area $\left(\alpha_{\mathrm{sb}}\right)$ for main steel reinforcement used in the tested beams were $0.00,0.062$ and 0.10 .

2. Bonded parts out the support $\left(\mathrm{L}_{1)}\right.$ for main steel reinforcement used in the tested beams were $5 \mathrm{~d}_{\mathrm{b}}, 10 \mathrm{~d}_{\mathrm{b}}$ and $15 \mathrm{~d}_{\mathrm{b}}$.

The beams were tested and the behavior includes the initiation of cracks and their propagation, the final mode of failure, the relationship between the applied load and the maximum induced deformation; in terms of deflection, slip, strain and slope for (HPC) beams reinforced with steel having variable relative rib area $\left(\alpha_{\mathrm{sb}}\right)$ were studied.

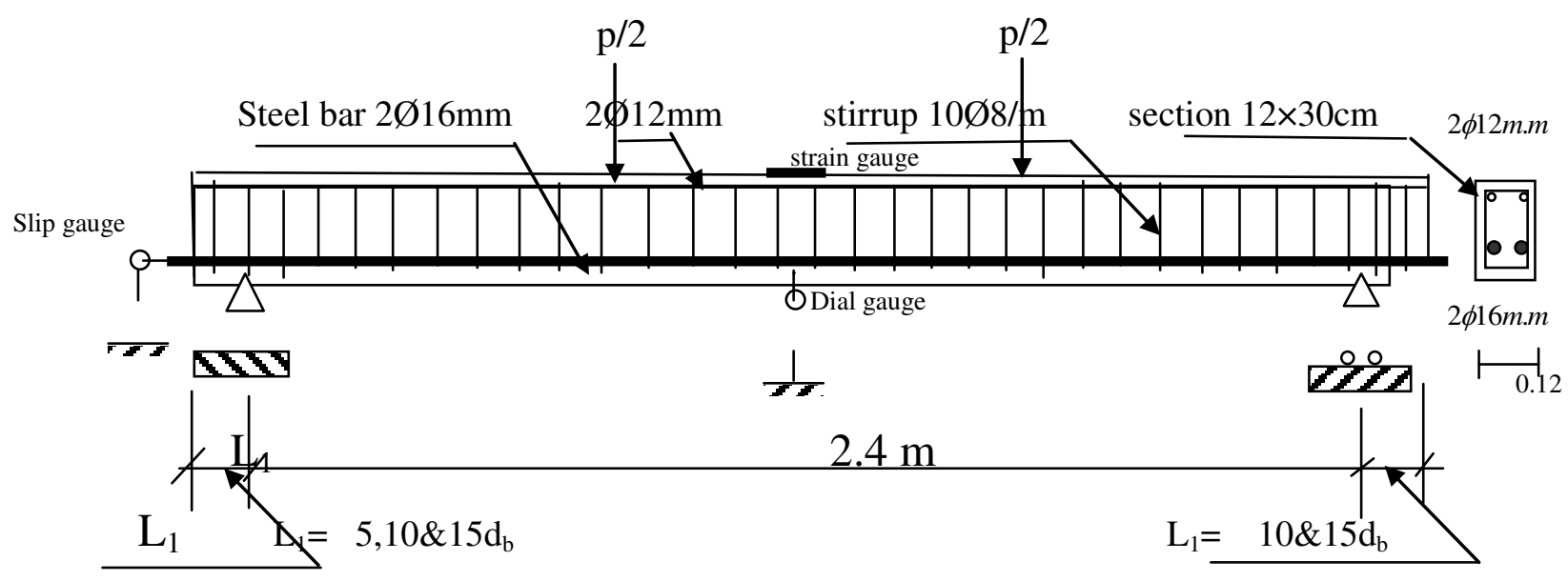

Fig.(1) : Details of R.C. Tested Beams

\subsection{Materials}

\subsubsection{High performance concrete (HPS)}

Concrete mix design was made to produce high performance or high strength concrete having 28-day cubic strength of $900 \mathrm{~kg} / \mathrm{cm}^{2}$. Concrete mix proportions are given in Table (1).

Table (1): Concrete mix proportions

\begin{tabular}{|c|c|c|c|c|c|}
\hline $\begin{array}{c}\text { Cement } \\
\mathrm{kg} / \mathrm{m}^{3}\end{array}$ & $\begin{array}{c}\text { fine } \\
\text { aggregate } \\
\mathrm{kg} / \mathrm{m}^{3}\end{array}$ & $\begin{array}{c}\text { Coarse } \\
\text { aggregate } \\
\mathrm{kg} / \mathrm{m}^{3}\end{array}$ & $\begin{array}{c}\text { Silica-fume } \\
\mathrm{kg} / \mathrm{m}^{3}\end{array}$ & $\begin{array}{c}\text { Super plasticizer } \\
(\text { B.V.S. }) \text { Litre } / \mathrm{m}^{3}\end{array}$ & $\begin{array}{c}\text { Water } \\
\text { liter } / \mathrm{m}^{3}\end{array}$ \\
\hline 500 & 550 & 1114 & 110 & 17.5 & 140 \\
\hline
\end{tabular}


Ordinary Portland cement was used (Assiut Cement). The coarse aggregate used was crushed basalt of $12 \mathrm{~mm}$ nominal size. Local natural sand was used as fine aggregate; Super plasticizer of is (B.V.S.)type, with optimum dosage $17.5 \mathrm{litre} / \mathrm{m}^{3}$ for concrete mix $; 110 \mathrm{~kg} / \mathrm{m}^{3}$ optimum dosage of silica fume with specific gravity 2.15 $\mathrm{t} / \mathrm{m}^{3}$.

\subsubsection{Steel reinforcement}

Plain bars of normal mild steel, its diameters $8 \mathrm{~mm}$ used for stirrups in RC beams and $16 \mathrm{~mm}$ main steel plain and deformed bars of high tensile steel were used as longitudinal tension reinforcements, the mechanical and geometrical properties of bars used in RC flexural members (beams), are given in table (2)

Table (2): Mechanical and Geometrical Properties of Plain and Deformed Bars.

\begin{tabular}{|c|c|c|c|c|c|c|c|}
\hline Group & Series & $\begin{array}{c}\mathrm{d}_{\mathrm{b}} \\
(\mathrm{mm})\end{array}$ & $\begin{array}{c}\text { Specimens } \\
\text { Notation }\end{array}$ & $\begin{array}{c}\text { Relative } \\
\text { Rib Area } \\
\left(\alpha_{\mathrm{sb}}\right)\end{array}$ & $\begin{array}{c}\text { Yield } \\
\text { stress }\left(\mathrm{f}_{\mathrm{y}}\right) \\
\mathrm{kg} / \mathrm{cm}^{2}\end{array}$ & $\begin{array}{l}\text { Ultimate } \\
\text { strength } \\
\left(\mathrm{f}_{\mathrm{u}}\right) \mathrm{kg} / \mathrm{cm}^{2}\end{array}$ & $\begin{array}{c}\% \\
\text { Elongation } \\
\% \mathrm{e}\end{array}$ \\
\hline \multirow{3}{*}{ B } & \multirow{3}{*}{$\begin{array}{l}\text { B1-3 } \\
\text { And } \\
\text { B4-6 } \\
\text { And }\end{array}$} & \multirow{3}{*}{16} & $\mathrm{~S} \mathrm{~m}$ & 0.000 & 3100 & 4600 & 28.6 \\
\hline & & & $\mathrm{B} \backslash \mathrm{S}$ & 0.062 & 4600 & 6700 & 19.2 \\
\hline & & & EZ•AL2 & 0.100 & 4750 & 6900 & 18.5 \\
\hline \multicolumn{2}{|c|}{ Top steel } & 12 & EZAL & 0.060 & 4600 & 6700 & 22.0 \\
\hline \multicolumn{2}{|c|}{ Stirrups } & 8.0 & Sm1 & 0.000 & 2900 & 4200 & 29.5 \\
\hline
\end{tabular}

\subsection{Test Procedure}

Nine simply supported beams of 28 days age were tested over a clear span of $2.4 \mathrm{~m}$ on two third-point loading. The available testing machine (EMS 60 tons $\mathrm{P}_{\mathrm{u}}$ ) was used in testing the beams under static loading. Average values of 28-days concrete compressive strength determined from cubes of $15 \mathrm{~cm}$ side length was $\left(907 \mathrm{~kg} / \mathrm{cm}^{2}\right)$

\section{3- TEST RESULTS}

\subsection{Crack Pattern and Mode of Failure}

The cracks pattern and modes of failure are explained for the tested reinforced high performance concrete (HPC) beams. Nine rectangular (HPC) reinforced concrete beams tested under static loading. Generally, three types of final mode of failure can be distinguished according to the bonded part out side the support $\left(\mathrm{L}_{1}\right)$ and relative rib area $\left(\alpha_{\mathrm{sb}}\right)$ as follows: -

(1) Bond failure $\left(\mathrm{P}_{\mathrm{u}}<\mathrm{P}_{\mathrm{uth}}\right) ;\left(\alpha_{\mathrm{sb}}=0.0\right)$.

(2) Flexural- Bond failure $\left(\mathrm{P}_{\mathrm{u}}<\mathrm{P}_{\mathrm{uth}}\right) ;\left(0.00<\alpha_{\mathrm{sb}}<0.062\right)$. 
(3) Flexural failure $\left(\mathrm{P}_{\mathrm{u}}>\mathrm{P}_{\mathrm{uth}}\right) ;\left(\alpha_{\mathrm{sb}}>0.062\right)$.

The effect of the various parameters on the cracks and final modes of failure for specimens will be discussed as follows.

\subsubsection{Effect of bonded part outside the support $\left(L_{1}\right)$}

The following noticed cracks for beams were observed as follows:

- The initiation of flexural cracks were observed at small value of bonded $\operatorname{part}\left(5 \mathrm{~d}_{\mathrm{b}}\right)$ for beams $(\mathrm{B} 1, \mathrm{~B} 2 \mathrm{and} \mathrm{B} 3)$ but they were not observed for beams (B7, B8 and B9) at greater value of bonded part $\left(15 \mathrm{~d}_{\mathrm{b}}\right)$

- The length of cracks and spacing between it were not affected by increased the bonded part, but the width of cracks were increased with increased the bonded part .

- The propagation of cracks for beams (B7, B8 and B9) was more than those compared for beams (B4, B5 and B6) and beams (B4, B5 and B6) were more than those compared for beams (B1, B2 and B3).

- The major cracks were formed at the max. Moment for all beams (at mid span of beams).

- The final modes of failure of beams (B1, B4 and B7) were noticed to be bond failure. For beams $\left(\mathrm{B} 2, \mathrm{~B} 3\right.$ and B5) with bonded part $=\left(5 \& 10 \mathrm{~d}_{\mathrm{b}}\right)$ were flexural-bond failure. For beams (B6, B8 and B9) with bonded part = $\left(10 \& 15 d_{b}\right)$ were flexural failure as shown in Figs (2),(3)\&(4).

\subsubsection{Effect of relative rib area $(\alpha \mathrm{sb})$.}

- The initiation of cracks were observed at smooth bar or small value of $\left(\alpha_{\mathrm{sb}}\right)$ for beams (B1, B4 and B7) but they were not observed for beams (B3, B6 and B9) at greater value of $\left(\alpha_{\mathrm{sb}}\right)$

- * The width of cracks and spacing between it were significantly large for beams (B1, B4 and B7) having smooth bars, but narrow for other beams having ribbed bars.

- The propagation of cracks for beams (B3, B6 and B9) and (B2, B5 and B8) were more than those compared for beams (B1,B4, and B7).

- The major cracks were formed at the max. Moment for all beams (at mid span of beams).

- The final modes of failure of beams (B1, B4 and B7) with smooth bars $\left(\alpha_{\mathbf{s b}}=\right.$ $0.0)$ were noticed to be bond failure. But were flexural-bond failure for beams (B2, B3 and B5) had ribbed bars with relative rib area $\left(\boldsymbol{\alpha}_{\text {.sb }}=0.062 \& 0.10\right)$; bonded part $=5 \& 10 \mathrm{~d}_{\mathrm{b}}$. For beams $(\mathrm{B} 6, \mathrm{~B} 8$ and B9) had ribbed bars with relative rib area $\left(\alpha_{\cdot s b}=0.062,0.10\right)$; bonded part $=10 \& 15 d_{b}$ were flexural failure. 


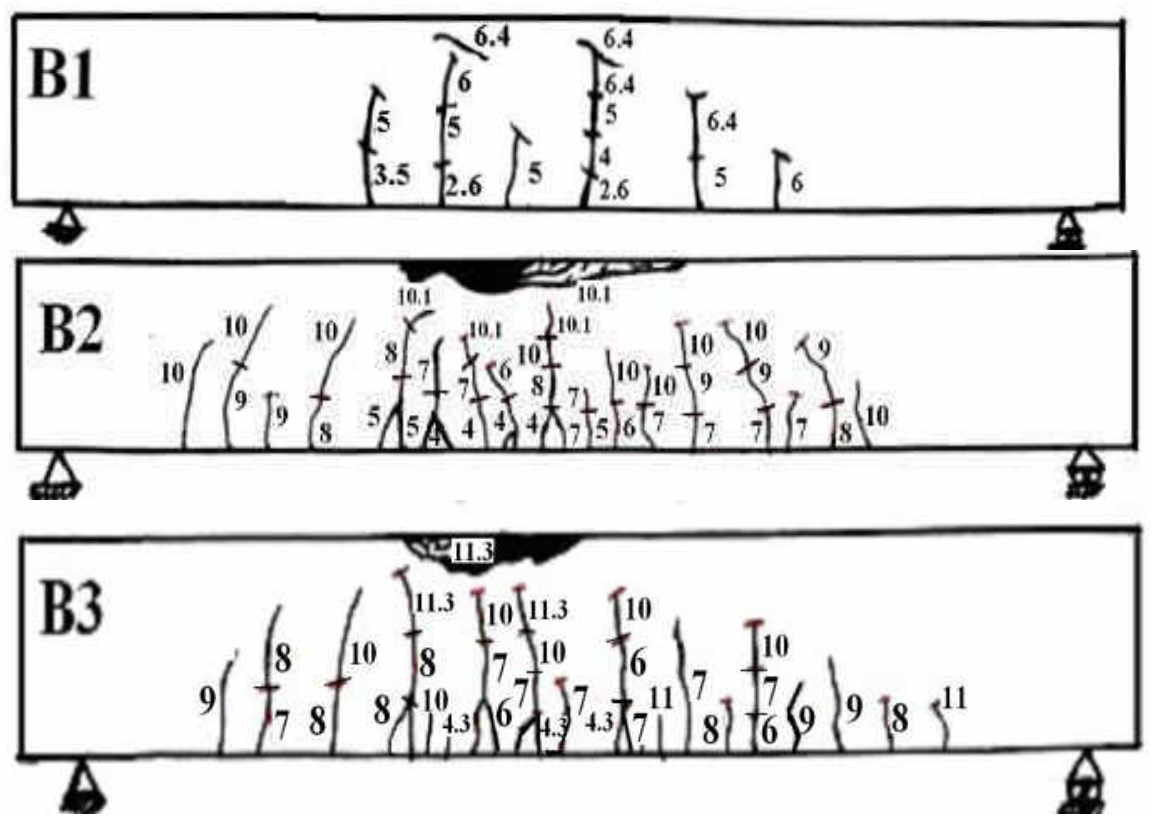

$$
\begin{array}{r}
\alpha_{\mathbf{s b}}=0.00 \\
\mathrm{~L}_{1}=5 \mathrm{~d}_{\mathrm{b}}
\end{array}
$$

$\alpha_{\mathbf{s b}}=0.062$ $\mathrm{L}_{1}=5 \mathrm{~d}_{\mathrm{b}}$

$$
\begin{array}{r}
\alpha_{\mathbf{s b}}=0.100 \\
L_{1}=5 d_{b}
\end{array}
$$

Fig. ( 2):Crack pattern of beams (B1. B2 and B3), $L_{1}=5 d_{b}$.

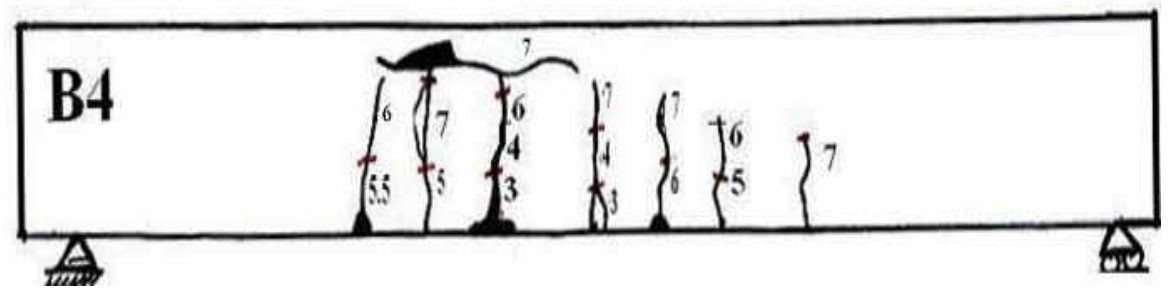

$$
\begin{gathered}
\alpha_{\mathrm{sb}}=0.00 \\
\mathrm{~L}_{1}=10 \mathrm{~d}_{\mathrm{b}}
\end{gathered}
$$

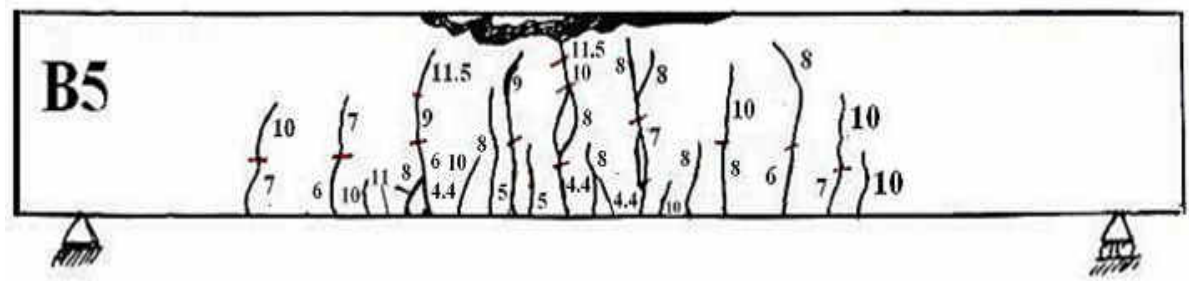

$$
\begin{array}{r}
\alpha_{\mathrm{sb}}=0.062 \\
\mathrm{~L}_{1}=10 \mathrm{~d}_{\mathrm{b}}
\end{array}
$$

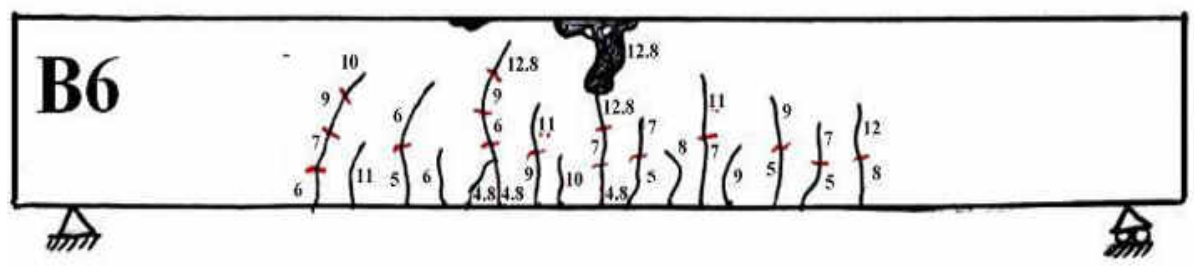

$$
\begin{aligned}
& \alpha_{\mathrm{sb}}=0.10 \\
& \mathrm{~L}_{1}=10 \mathrm{~d}_{\mathrm{b}}
\end{aligned}
$$

Fig. (3 ):Crack pattern of beams (B4. B5 and B6), $L_{1}=10 d_{b}$ 


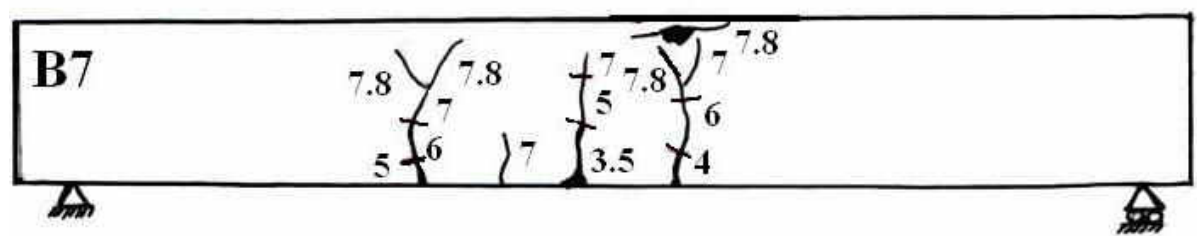

$$
\begin{aligned}
& \alpha_{\mathrm{sb}}=0.00 \\
& \mathrm{~L}_{1}=15 \mathrm{~d}_{\mathrm{b}}
\end{aligned}
$$
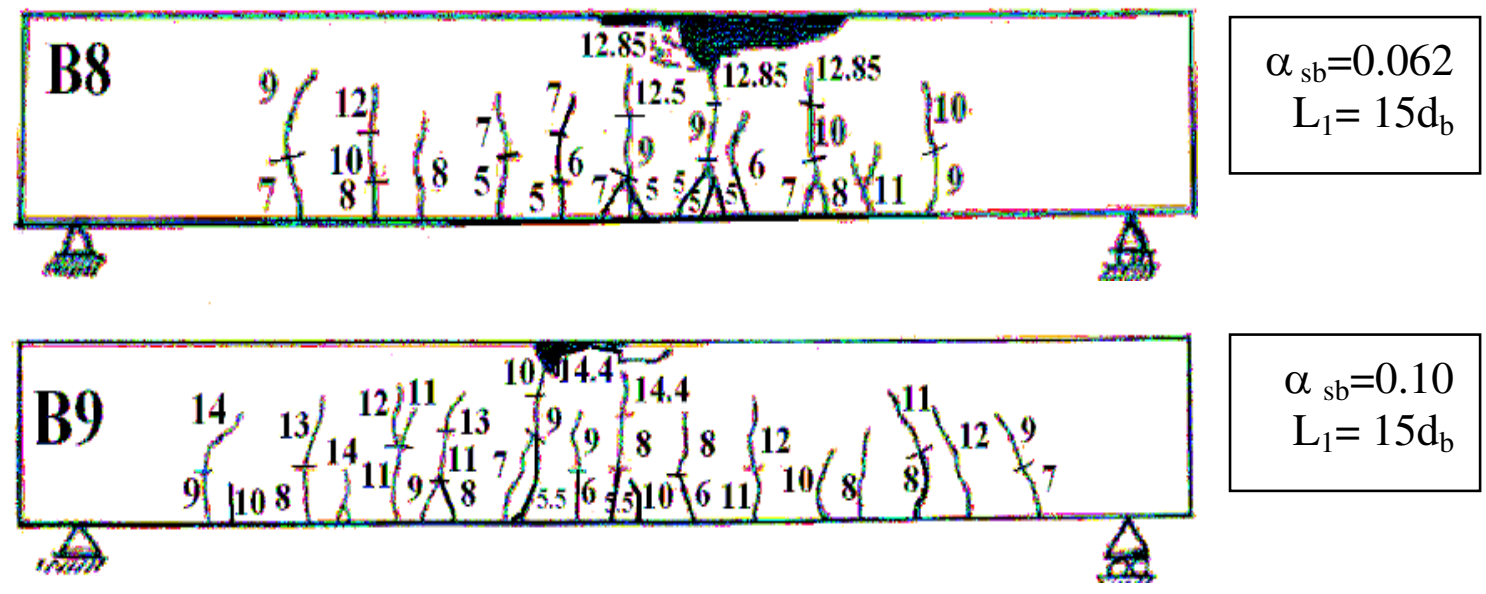

$\alpha_{\mathrm{sb}}=0.10$
$\mathrm{~L}_{1}=15 \mathrm{~d}_{\mathrm{b}}$

Fig. (4 ):Crack pattern of beams (B7 . B8 and B9), $L 1=15 d_{b}$

\section{3-2 Measured Deformations}

The load- mid span deflection; the load-end slip; the load-concrete strain and the loadslope curves obtained from tests are shown in Fig.5 to 12. The effect of the various parameters on the load- mid span deformations characteristics will be discussed as follows.

\subsection{1 - Load - mid span deflection}

The measured and theoretical values of mid span deflection are plotted versus the applied load from starting the loading up to failure as shown in Fig. (5). All plotted values indicated that the deflection increases as the applied load increases and the relation between the applied load and the mid span deflection tends to be in linear or non linear relation depending on the applied load level, and the relation depend on the relative rib area $\left(\alpha_{\mathrm{sb}}\right)$, as well as the bonded part of steel bars $\left(\mathrm{L}_{1}\right)$. The theoretical central deflection at all loads was calculated by using $\mathrm{ACI}{ }^{(8)}$ equations as.

$$
\begin{aligned}
& \boldsymbol{\delta}=(23 / 648)_{*}\left[\left(\mathrm{P}_{\mathrm{u}} / 2\right) * \mathrm{~L}^{3} /\left(\mathrm{E}_{\mathrm{c}} * \mathrm{I}_{\mathrm{e}}\right)\right] \ldots \ldots \ldots \ldots \ldots \ldots \ldots \ldots \ldots \ldots \ldots \ldots \ldots \ldots \ldots \ldots \ldots \ldots \ldots \ldots \ldots \ldots \\
& \mathrm{E}_{\mathrm{c}}=3320 \sqrt{ } f_{\mathrm{c}}^{\prime}+6900 \mathrm{Mpa} \ldots \ldots \ldots \ldots \ldots \ldots \ldots \\
& \mathrm{I}_{\mathrm{e}}=\left(\mathrm{M}_{\mathrm{cr}} / \mathrm{M}_{\mathrm{a}}\right)^{3} \mathrm{I}_{\mathrm{g}}+\left(1-\left(\mathrm{M}_{\mathrm{cr}} / \mathrm{M}_{\mathrm{a}}\right)^{3} \mathrm{I}_{\mathrm{cr}}\right) \ldots \ldots \ldots \ldots \ldots \\
& \mathrm{M}_{\mathrm{cr}}=\left(\mathrm{f}_{\mathrm{ctr}} \cdot \mathrm{I}_{\mathrm{g}}\right) / \mathrm{y}_{\mathrm{ct}}, \mathrm{f}_{\mathrm{ctr}}=0.94 \sqrt{ } f_{\mathrm{c}}^{\prime} \quad \mathrm{M} \mathrm{pa}, \mathrm{I}_{\mathrm{g}}=\mathrm{bt}^{3} / 12, \mathrm{y}_{\mathrm{ct}}=\mathrm{t} / 2, \mathrm{~b}=12 \mathrm{~cm}, \mathrm{t}=30 \mathrm{~cm}
\end{aligned}
$$




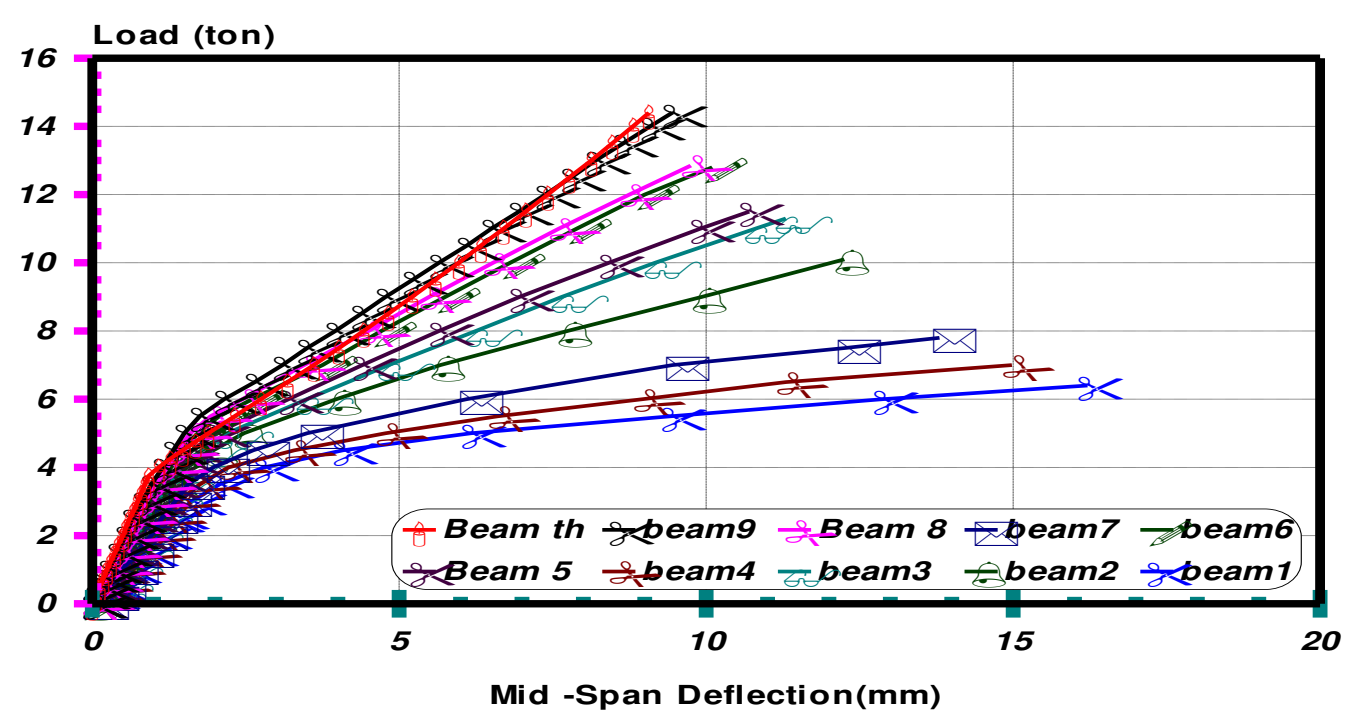

Fig (5): Load - Mid Span Deflection Relationship for Tested Beams.

\section{Effect of bonded part outside the support $\left(\mathrm{L}_{1}\right)$}

The values of the applied load for tested beams were increased with the increase of bonded part for all cases of beams.

\section{Effect of relative rib area $(\alpha \mathrm{Sb})$}

The values of the applied load from beam test increased with the increases of the relative rib area $\left(\alpha_{\mathrm{Sb}}\right)$. Generally the shape of the load-mid span deflection curve of tested prismatic beams for small relative rib area $\left(\alpha_{\mathrm{Sb}}\right)$ differs from the shape of the load- mid span deflection curve of tested prismatic beams for high relative rib area $\left(\alpha_{\mathrm{Sb}}\right)$.

\subsubsection{Load - slip relationship}

Stresses for concrete and steel are transferred between the two materials if they work together in beams The term "bond" is used to describe the means by which slip between concrete and steel is prevented or minimized wherever the tensile or compressive stress in a bar changes or not . Bond stresses must act along the surface of the bar to produce the change. Bond stresses are the longitudinal shearing stresses acting on the surface between the steel and concrete. Bond resistance of plain steel bars is largely dependent on adhesion between the bar and concrete. But even after adhesion is broken, friction between the materials continuous to provide a considerable bond resistance. Friction resistance is low for a smooth bar surface. Deformed bars have larger bond capacity because of the interlocking of the ribs with the surrounding concrete .The mechanism of bond is comprised of three main components: chemical adhesion, friction, and mechanical interlock between bar ribs and concrete .

The slip is plotted against the applied load from the starting of loading up to failure as shown in Fig. (6). 


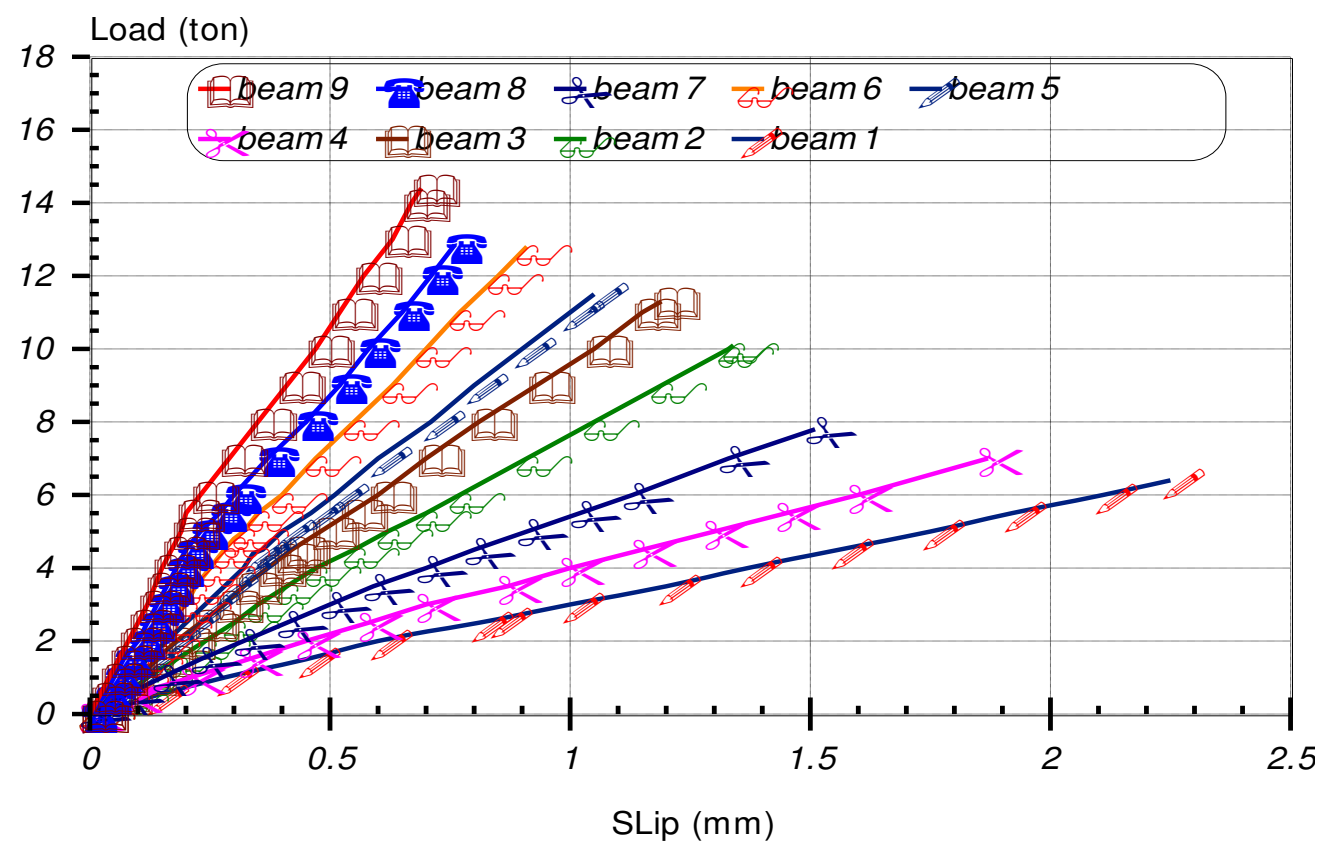

Fig (6): Load - End Slip Relationship for Tested Beams

\section{Effect of bonded part outside the support (L1)}

The measured loads for beams series (B7; B8 and B9) having bonded part $\left(\mathrm{L} 1=15 \mathrm{~d}_{\mathrm{b}}\right)$ were larger than that measured for series $\left(\mathrm{B} 4\right.$, B5 and B6) having $\left(\mathrm{L}_{1}=10\right.$ $\left.d_{b}\right)$. A1so, the measured loads for series (B4, B5 and B6) having $\left(L_{1}=10 d_{b}\right)$ were larger than that measured for series (B4, B5 and B6) having $\left(\mathrm{L}_{1}=5 \mathrm{~d}_{\mathrm{b}}\right)$ as shown in Fig. (6) .The measured loads as a result of the increase of the bonded part for steel should be increased. But the measured end slip due to the increase of the bond between steel and concrete at the beams should be decreased.

\section{Effect of relative rib area for steel $\left(\alpha_{\mathrm{sb}}\right)$}

The measured values of the load and slip for all tested beams indicated that the end slips decrease with the increase of the relative rib area $\left(\alpha_{\mathrm{sb}}\right)$. Also, the loads increase with the increase of relative rib area $\left(\alpha_{\mathrm{sb}}\right)$.

\subsubsection{Concrete strain at the top compression zone for the beams}

The measured strain values are plotted versus the applied load from starting loading up to failure as shown in Fig. (7). Generally, the compressive concrete strain increases as the applied load increases up to the failure loads .The rate of increases of compressive concrete strain due to applied load depends on the bonded part and relative rib area ( $\alpha$ s), the effect of these parameters can be observed from such curves. 


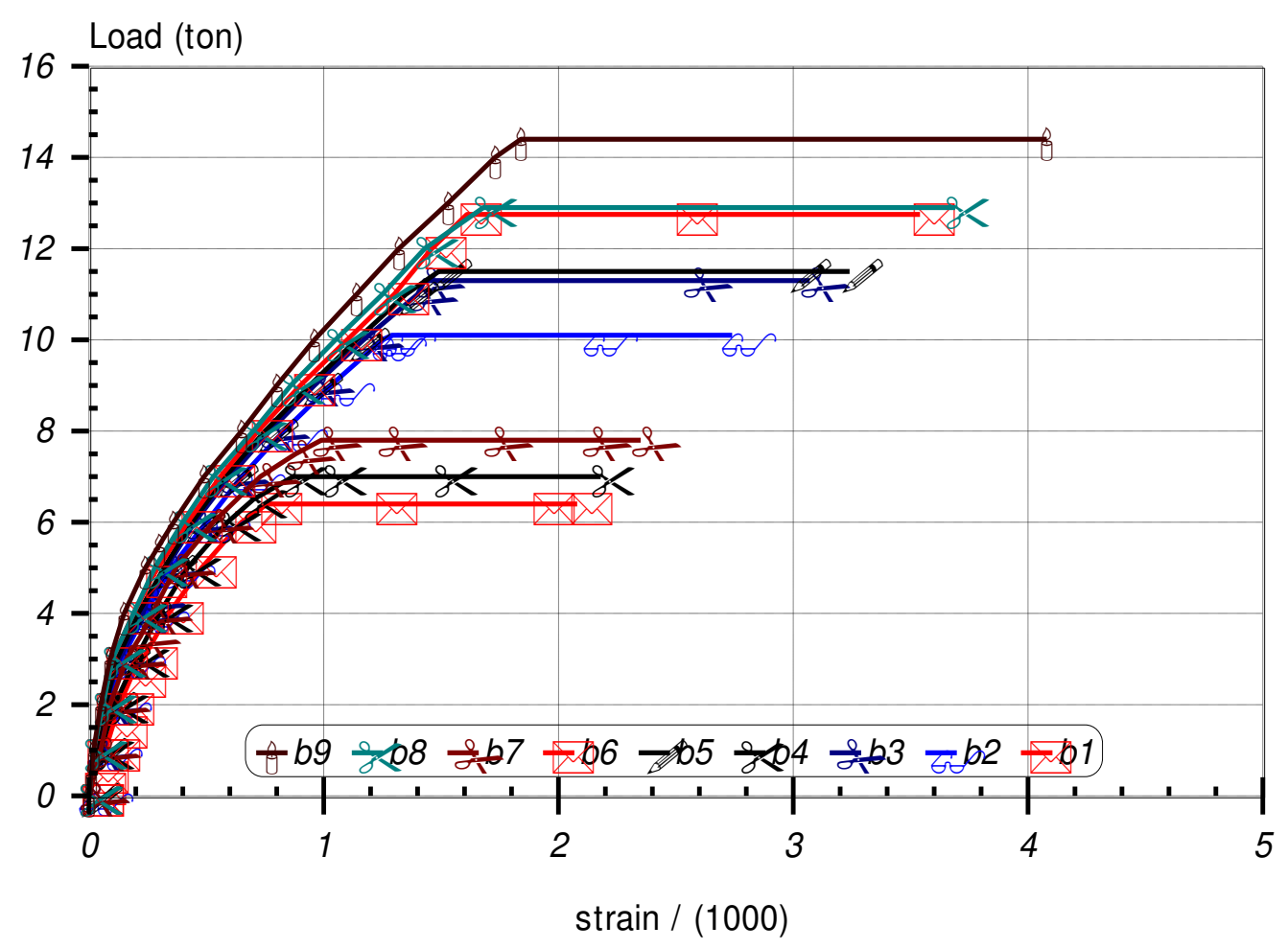

Fig (7): Load - Compressive Concrete Strain at Top Mid Span Relationship for Tested Beams

\section{Effect of bonded part outside the support $\left(L_{1}\right)$}

The measured values of compressive concrete strain for all tested beams decrease with the increase of bonded part as shown in Fig. (7).

\section{Effect of relative rib area $\left(\alpha_{\mathrm{sb}}\right)$}

The measured values of the concrete strain of all tested beams decrease with the increase of relative rib area $\left(\alpha_{\mathrm{sb}}\right)$.

\subsubsection{Load-Slope characteristics}

The maximum measured slope at the center of hinged support of the tested beams is plotted versus the applied load from zero loading up to failure as shown in Fig. (8). Generally, the slope at the center of hinged support increases as the applied load increases up to limit of cracking load, beyond this limit a sharp decrease in the rate of increase of the ultimate slope was observed and after that increasing in the slope was accompanied with a slight increasing of the applied load up to failure load.

The effect of the studied variables on the load-slope will be discussed as follows: - 


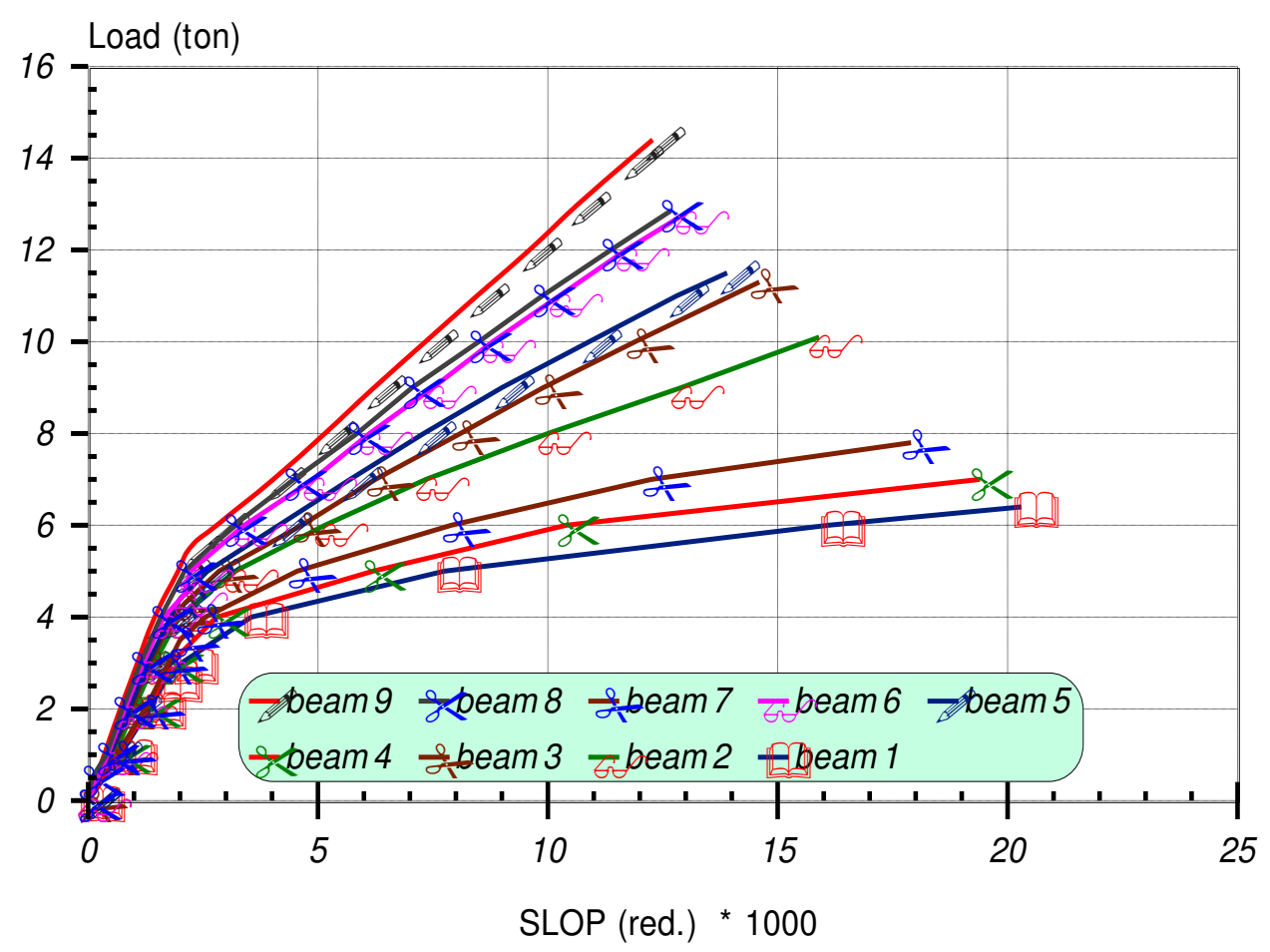

Fig (8): Load - End Slope Relationship for Tested Beams

\section{Effect of bonded part outside the support $\left(L_{1}\right)$}

The values of slope for all tested beams increase with the decrease of the bonded part as a result of reduction in bond stresses between main steel and concrete for beams.

\section{Effect of relative rib area ( $(\alpha \mathrm{sb})$}

The values of slope for all tested beams increase with the decrease of the value of relative rib area $\left(\alpha_{\mathrm{sb}}\right)$ due to the increase of the bond between the steel and concrete of beams.

\section{4- DISCUSSIONS OF RESULTS}

This item describes and interprets the analysis of the obtained test results of the HPC beams. The analysis includes the relationship between the values of the cracking and ultimate loads, slips deflections, concrete strains and slope versus bonded part of steel bars outside the support $\left(\mathrm{L}_{1}\right)$ and relative rib area of bars $\left(\alpha_{\mathrm{sb}}\right)$ for tested beams. The characteristics of tested beams at cracking and ultimate loads are given in tables (3) and (4). 
Table (3) :Values of cracking loads and deformations at cracking loads for tested beams.

\begin{tabular}{|c|c|c|c|c|c|c|c|}
\hline Series & $\begin{array}{l}\text { Bonded } \\
\text { Part } \\
(\mathrm{mm})\end{array}$ & $\begin{array}{c}\text { Relative } \\
\text { rib area } \\
\left(\alpha_{\mathrm{sb}}\right)\end{array}$ & $\begin{array}{l}\mathrm{P}_{\mathrm{cr}} \\
(\text { ton })\end{array}$ & $\begin{array}{c}\text { Deflection } \\
\Delta_{\mathrm{cr}} \\
(\mathrm{mm}) \mathrm{at} \\
\mathrm{P}_{\mathrm{cr}}\end{array}$ & $\begin{array}{l}\text { Slip } \\
(\mathrm{mm}) \\
\text { at } \mathrm{P}_{\mathrm{cr}}\end{array}$ & $\begin{array}{c}\underset{3}{\operatorname{Strain}} * 10 \\
\text { at } \mathrm{P}_{\mathrm{cr}}\end{array}$ & $\begin{array}{l}\text { Slope } * 10 \\
\text { at } \mathrm{P} \\
\text { cr }\end{array}$ \\
\hline B1 & $5 \mathrm{~d}_{\mathrm{b}}$ & 0.000 & 2.6 & 1.34 & 0.81 & 0.18 & 1.68 \\
\hline B2 & $10 d_{b}$ & 0.062 & 4 & 1.53 & 0.47 & 0.24 & 1.98 \\
\hline B3 & $15 d_{b}$ & 0.100 & 4.3 & 1.62 & 0.40 & 0.25 & 2.1 \\
\hline B4 & $5 \mathrm{~d}_{\mathrm{b}}$ & 0.000 & 3 & 1.41 & 0.70 & 0.20 & 1.8 \\
\hline B5 & $10 d_{b}$ & 0.062 & 4.4 & 1.58 & 0.34 & 0.26 & 2.0 \\
\hline B6 & $15 d_{b}$ & 0.100 & 4.8 & 1.62 & 0.30 & 0.27 & 2.1 \\
\hline B7 & $5 d_{b}$ & 0.000 & 3.5 & 1.56 & 0.59 & 0.22 & 2.0 \\
\hline B8 & $10 d_{b}$ & 0.062 & 5 & 1.6 & 0.23 & 0.28 & 2.1 \\
\hline B9 & $15 \mathrm{~d}_{\mathrm{b}}$ & 0.100 & 5.5 & 1.7 & 0.20 & 0.30 & 2.21 \\
\hline
\end{tabular}

Table (4) :Values of ultimate loads and deformations at ultimate loads for tested beams.

\begin{tabular}{|c|c|c|c|c|c|c|c|c|}
\hline Series & $\begin{array}{c}\text { Bonded } \\
\text { Part }\end{array}$ & $\begin{array}{c}\text { Relative } \\
\text { rib area } \\
\left(\alpha_{\mathrm{sb}}\right)\end{array}$ & $\begin{array}{c}\mathrm{P}_{\mathrm{u}} \\
\text { (ton) }\end{array}$ & $\begin{array}{c}\text { Deflection } \\
\delta_{\mathrm{u}}(\mathrm{mm}) \text { at } \\
\mathrm{P}_{\mathrm{u}}\end{array}$ & $\begin{array}{l}\text { Slip } \\
(\mathrm{mm}) \\
\text { at } \mathrm{P}_{\mathrm{u}}\end{array}$ & $\begin{array}{l}\text { Strain } \\
\times 10^{3} \\
\text { at } \mathrm{P}_{\mathrm{u}}\end{array}$ & $\begin{array}{c}\text { Slop } \\
\mathrm{e} \times \\
10^{3} \\
\text { at } \mathrm{P} \\
. \text { u }\end{array}$ & $\begin{array}{l}\text { Mode of } \\
\text { failure }\end{array}$ \\
\hline B1 & $5 d_{b}$ & 0.000 & 6.4 & 16.21 & 2.25 & 0.75 & 20.3 & Bond failure \\
\hline B2 & $10 d_{b}$ & 0.062 & 10.1 & 12.25 & 1.34 & 1.29 & 15.9 & $\begin{array}{c}\text { Flexural- } \\
\text { Bond failure }\end{array}$ \\
\hline B3 & $15 d_{b}$ & 0.100 & 11.3 & 11.3 & 1.19 & 1.46 & 14.6 & $\begin{array}{c}\text { Flexural- } \\
\text { Bond failure }\end{array}$ \\
\hline B4 & $5 \mathrm{~d}_{\mathrm{b}}$ & 0.000 & 7 & 14.98 & 1.87 & 0.87 & 19.4 & Bond failure \\
\hline B5 & $10 d_{b}$ & 0.062 & 11.5 & 10.70 & 1.06 & 1.49 & 13.9 & $\begin{array}{c}\text { Flexural- } \\
\text { Bond failure }\end{array}$ \\
\hline B6 & $15 d_{b}$ & 0.100 & 12.8 & 10.01 & 0.91 & 1.65 & 13.0 & $\begin{array}{c}\text { Flexural } \\
\text { failure }\end{array}$ \\
\hline B7 & $5 d_{b}$ & 0.000 & 7.8 & 13.80 & 1.51 & 0.99 & 17.9 & Bond failure \\
\hline B8 & $10 d_{b}$ & 0.062 & 12.85 & 9.75 & 0.76 & 1.68 & 12.7 & $\begin{array}{c}\text { Flexural } \\
\text { failure }\end{array}$ \\
\hline B9 & $15 d_{b}$ & 0.100 & 14.4 & 9.45 & 0.69 & 1.84 & 12.3 & $\begin{array}{c}\text { Flexural } \\
\text { failure }\end{array}$ \\
\hline
\end{tabular}




\section{1- Cracking and Ultimate Load}

The values of the obtained cracking $\left(\mathrm{P}_{\text {cr. }}\right)$ and the ultimate loads $\left(\mathrm{P}_{u}\right)$ for tested beams are given in tables (3) and (4).The theoretical values of the ultimate load ( $\left.\mathrm{P}_{\text {uth }}\right)$ can be determined according to the smallest value of the following cases (a)- Due to bending ,(b)- Due to shear or(c)-Due to bond .The critical case was due to bending as follow by (ACI code 1995$)^{8}$ :

The theoretical values of the cracking load $\left(\mathrm{P}_{\text {crth }}\right)$ can be determined according to $(\mathrm{ACI})^{(8)}$. Where $\mathrm{P}_{\text {.cth }}=\left(\mathrm{f}_{\text {. ctr }} . \mathrm{I}_{\mathrm{g}}\right) / \mathrm{y}$.ct, $\mathrm{f}_{\text {ctr }}=0.94 \sqrt{ } f_{\mathrm{c}}^{\prime} \mathrm{M}$ pa .Then $\mathrm{P}_{\text {crth }}=3.81$ ton . $\mathrm{M}_{\mathrm{n}}=\mathrm{A}_{\mathrm{s}} f_{\mathrm{y}} \mathrm{d}\left(1-0.59 f_{\mathrm{y}} / f_{\mathrm{c}}^{\prime}\right)$ in $-1 \mathrm{~b}, f_{\mathrm{c}}^{\prime}=0.9 \mathrm{f}_{\mathrm{c}}, \quad \mathrm{P}_{\text {uth }}=2.5 \mathrm{M}_{\mathrm{n}}, \rho=\mathrm{A}_{\mathrm{s}} / \mathrm{A}_{\mathrm{c}}$ Then $\mathrm{P}_{\text {uth }}=2.7 \mathrm{f}_{\mathrm{y}}\left(1-0.9 \mathrm{f}_{\mathrm{y}} / 10^{5}\right)$ $\mathrm{kg}$.

The theoretical values of the ultimate load were $8.14 ; 11.91 ; 12.28$ ton for bars $\mathrm{S} \mathrm{m} ; \mathrm{BIS}$; EZ•AL2 respectively.

\section{Influence of Bonded Part $\left(L_{b}\right)$}

The values of the cracking $\left(\mathrm{P}_{\text {cr }_{\mathrm{r}}}\right)$ and the ultimate loads $\left(\mathrm{P}_{\mathrm{u}}\right)$ for tested beams increase with the increase of the bonded part outside the center of support $\left(\mathrm{L}_{1}\right)$ of the main steel bars, as shown in Fig (9).

The values of the cracking $\left(\mathrm{P}_{\text {.cr }}\right)$ and ultimate $\left(\mathrm{P}_{\mathrm{u}}\right)$ loads for HPC beams reinforced with steel bars having bonded part outside the center of support $\left(\mathrm{L}_{1}\right)$ of $10 \mathrm{~d}_{\mathrm{b}}$ and $15 \mathrm{~d}_{\mathrm{b}}$ compared to the corresponding values for HPC beams reinforced with steel bars having bonded part outside the center of support $\left(\mathrm{L}_{1}=5 \mathrm{~d}_{\mathrm{b}}\right)$ for main steel bars $(\mathrm{S} \mathrm{m}),(\mathrm{B} \backslash \mathrm{S})$ and (EZ.AL1) were respectively as follows:-

(i) For cracking load

For bar (S m ).the compared values were 115.4 and $134.6 \%$.

For bar $(\mathrm{B} \backslash \mathrm{S})$ the compared values were 110 and $125 \%$.

For bar (EZ.AL1) the compared values were 111.6 and $127.9 \%$.

(ii) For ultimate load)

For bar (S m ).the compared values were 109.4 and $121.9 \%$.

For bar (B\S) the compared values were 113.9 and $127.2 \%$.

For bar (EZ.AL1) the compared values were 113.3 and $127.4 \%$.

\section{Influence Of Relative Rib Area $\left(\alpha_{s b}\right)$}

The values of the cracking $\left(\mathrm{P}_{\mathrm{cr}}\right)$ and the ultimate loads $\left(\mathrm{P}_{\mathrm{u}}\right)$ for tested beams increase with the increase of the relative rib area $\left(\alpha_{\mathrm{sb}}\right)$ as shown in Fig.(10) and table (4) .

The values of the cracking and the ultimate loads for bars $\left(B \backslash S \alpha_{\mathrm{sb}==0.062}\right)$ and (EZ.AL2 $\alpha_{\mathrm{sb}=0.10}$ ) compared to the corresponding values for bar ( $\mathrm{S} \mathrm{m} \alpha_{\cdot \mathrm{sb}=0.00}$ ) at different bonded part outside the center of support $\left(\mathrm{L}_{1}\right)$ were respectively as follows:

(a)-For cracking load

For $\mathrm{L}_{1}=5 \mathrm{~d}_{\mathrm{b}}$ the compared values were 153.9 and $165.4 \%$.

For $\mathrm{L}_{1}=10 \mathrm{~d}_{\mathrm{b}}$ the compared values were 146.7 and $160 \%$.

For $\mathrm{L}_{1}=15 \mathrm{~d}_{\mathrm{b}}$ the compared values were 142.9 and $157.1 \%$.

(b)-For ultimate load

For $\mathrm{L}_{1}=5 \mathrm{~d}_{\mathrm{b}}$ the compared values were 157.8 and $176.6 \%$. 
For $\mathrm{L}_{1}=10 \mathrm{~d}_{\mathrm{b}}$ the compared values were 164.3 and $182.9 \%$.

For $\mathrm{L}_{1}=15 \mathrm{~d}_{\mathrm{b}}$ the compared values were 164.8 and $184.6 \%$.

The experimental to theoretical values of the cracking and ultimate load for beams (B1 to B9) were respectively as follows:

(a)-For cracking load

The compared values were $68,105,113,79,115,126,92,131$, and $144 \%$.

(b)-For ultimate load

The compared values were 79, 85, $92,86,97,104,96,108,117 \%$.
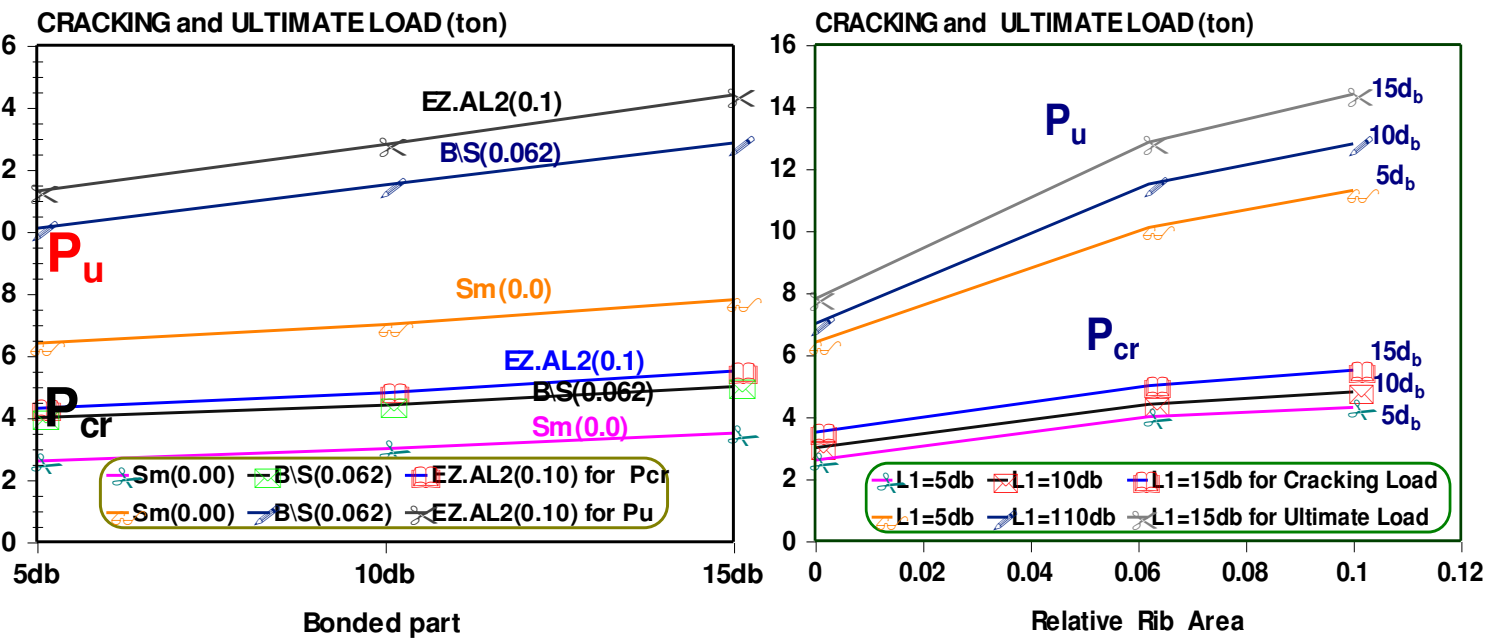

Fig (9): Cracking and Ultimate Load versus Bonded Part $\left(\mathrm{L}_{1}\right)$ of steel bar for tested beams

Fig (10 ): Cracking and Ultimate Load versus relative rib area of steel bar for tested beams

\subsection{Deformations}

The values of the obtained deformation at cracking $\left(\mathrm{P}_{\mathrm{cr}}\right)$ and the ultimate loads $\left(\mathrm{P}_{\mathrm{u}}\right)$ for tested beams are given in tables (3) and (4). The values of this deformation depend on the relative rib area $\left(\alpha_{\mathrm{sb}}\right)$, as well as the bonded part of steel bars $\left(\mathrm{L}_{1}\right)$.

\section{Influence of Bonded Part $\left(L_{b}\right)$}

At the constant loads, the deflections, end slip, concrete strain and slope at end support, decrease with the increase of the bonded part outside the center of support $\left(\mathrm{L}_{1}\right)$.

At the cracking load ( $\mathrm{P}$ cr), the deflections, concrete strain and slope increases with the increase of the relative rib $\left(\alpha_{\mathrm{sb}}\right)$ due to increase of the cracking loads except the end slip decrease with the increase of the relative rib $\left(\alpha_{\mathrm{sb}}\right)$, The rate of increases become more pronounced for cracking loads but less for the above deformations (deflection, concrete strain and slope ) .

At the ultimate loads $\left(\mathrm{P}_{\mathrm{u}}\right)$ for, the deflections, end slip, concrete strain and slope at end support decrease with the increase of the bonded part outside the center of support $\left(\mathrm{L}_{1}\right)$. 
The decrease of deflections for increases the bonded part resulting to decrease the slip and increase the bond strength which accompanied with decrease length and width of cracks. Therefore, the stiffness of these parameters with bonded part outside the center of support $15 \mathrm{~d}_{1}$ were more than those for beams with bonded part outside the center of support $5 \mathrm{~d}_{1}$, as shown in Figs .(11) (13)(15)\& (17)

\section{Influence Of Relative Rib Area $\left(\alpha_{s b}\right)$}

At the constant load, the deflections, end slip, concrete strain and slope at end support decrease with the increase of the relative rib area $\left(\alpha_{\mathrm{sb}}\right)$.

At the cracking loads(Pcr), the deflection, concrete strain and slope increases with the increase of the relative rib $\left(\alpha_{\mathrm{sb}}\right)$ due to increase of the cracking loads except the end slip decrease with the increase of the relative rib $\left(\alpha_{\mathrm{sb}}\right)$, The rate of increases become more pronounced for cracking loads but less for the above deformations (deflection, concrete strain and slope ).

At the ultimate loads, the deflection end slip, concrete strain and slope at end support decreases with the increase of the relative rib $\left(\alpha_{\mathrm{sb}}\right)$.

The reduction of the values of the deformations for the beams reinforced with steel bar ((BIS ,EZ.AL2)) having $\left(\alpha_{\mathrm{sb}}=0.062,0.10\right)$ may be due to the increase of the bond strength and the decrease of the slip resulting from the increase of the relative rib area $\left(\alpha_{\mathrm{sb}}\right)$ and the decrease in number, length and width of cracks. Therefore, the stiffness of these beams were more than the corresponding stiffness for beams reinforced with steel bar $(\mathrm{S} \mathrm{m})$ having $\left(\alpha_{\mathrm{sb}}=0.00\right)$ as shown in Figs. (12) (14) (16) \& (18). The experimental to theoretical values of the deflections at cracking and ultimate load for beams (B1 to B9) were respectively as follows:

(a)-For cracking load

The compared values $209,142,124,190,114,94,180,85,73 \%$.

(b)-For ultimate load

The compared values were 523, 203, 163, 415, 152, 324, 122, and $104 \%$.

Deflection at cracking and ultimate load $(\mathrm{mm})$

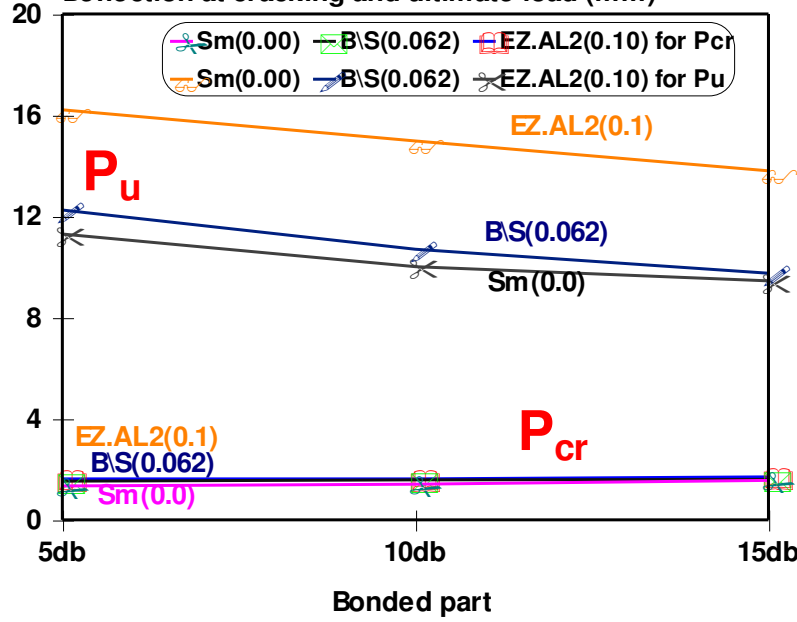

Fig (11) Deflection at cracking and ultimate load versus

Bonded part (L1) of steel bar for tested beams

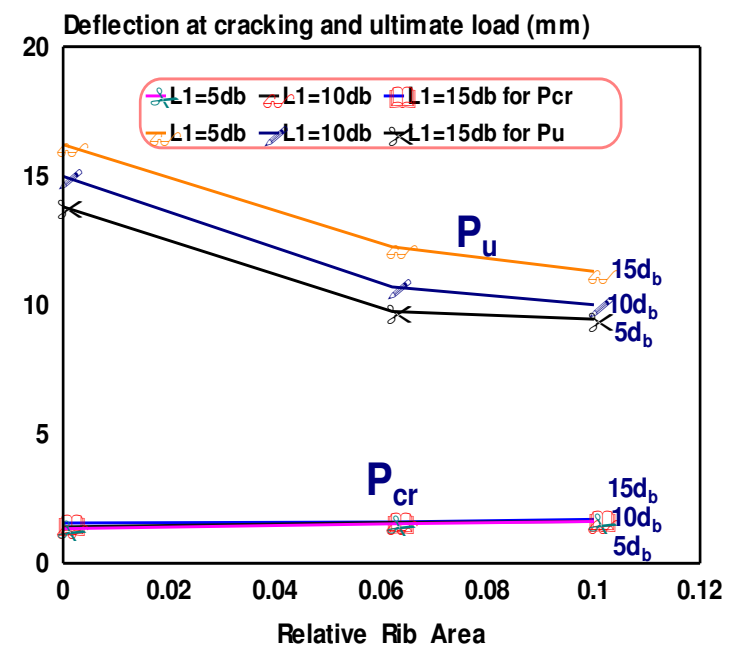

Fig(12):Deflection at cracking and ultimate load versus relative rib area of steel bar for tested beams . 
SLIP $(\mathrm{mm})$ at cracking and ultimate load

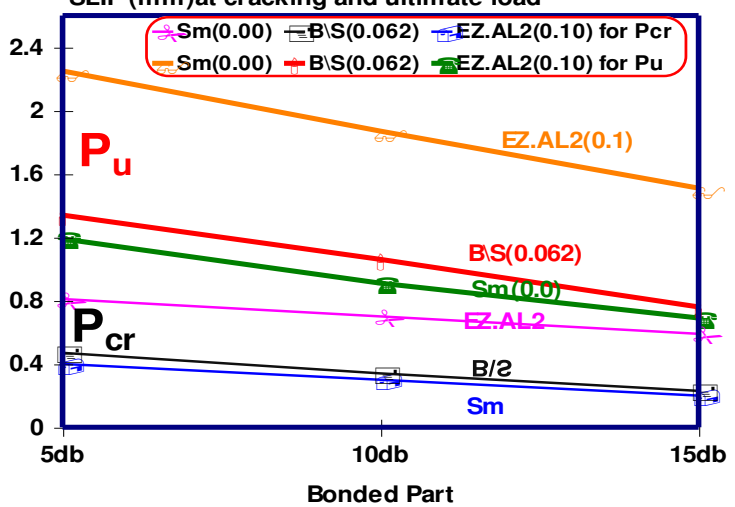

Fig (13): Slip at cracking and ultimate load versus bonded Part (L1) of steel bars for tested beams.

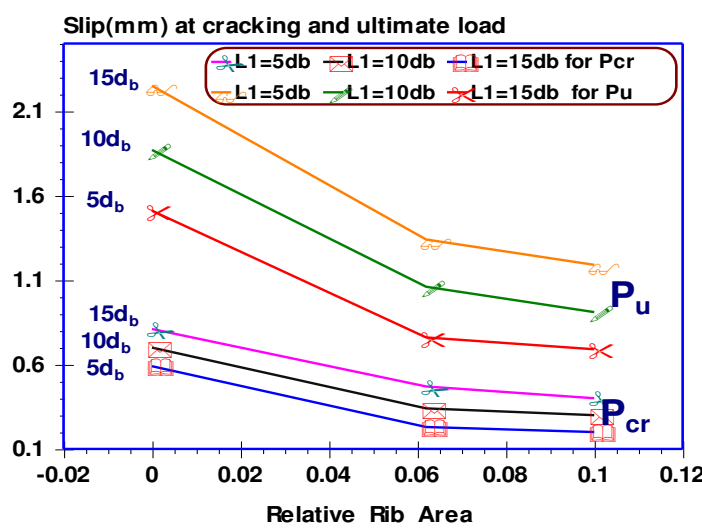

Fig (14) Slip at cracking and ultimate load versus relative ribarea of steel bar for tested beams .

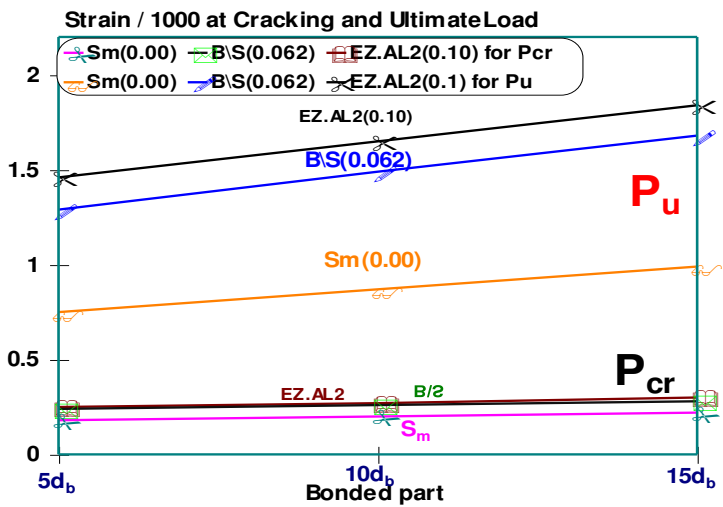

Fig. (15): Strain at cracking and ultimate load versus Bonded Part (L1) of steel bars for tested beams.

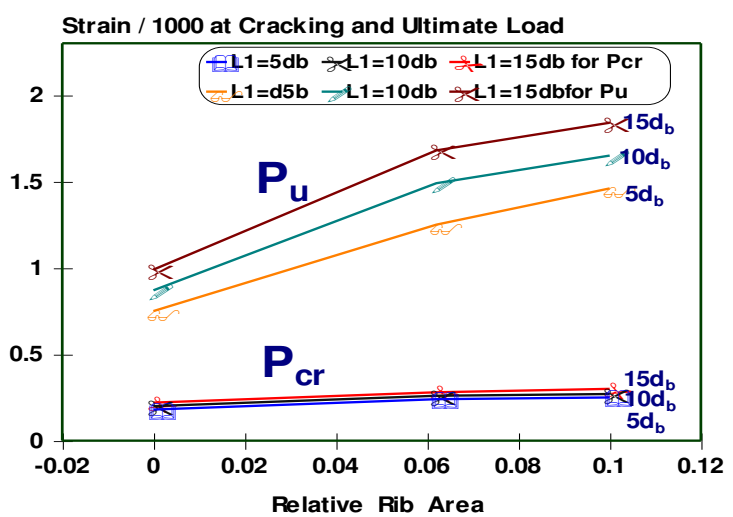

Fig. (16): Strain at cracking and ultimate load versus relative Rib area of steel bar for tested beams
SLOPE (red) / 1000 at cracking and ultimate load

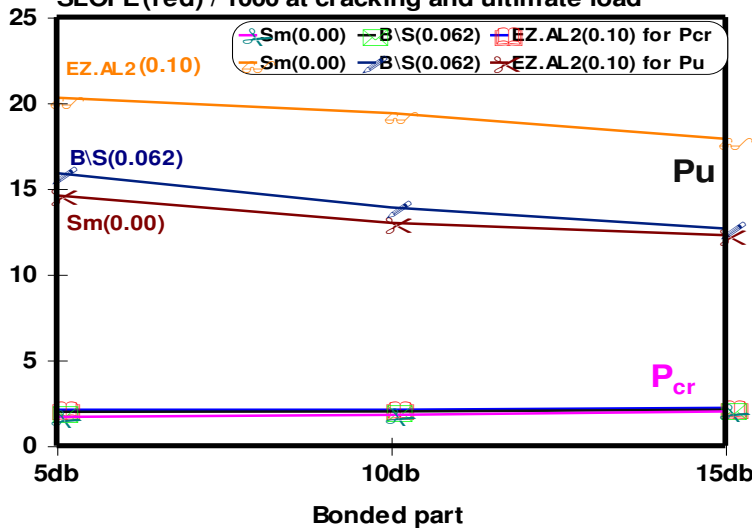

Fig. (17):Slope at cracking and ultimate load versus Bonded part (L1) of steel bar for tested beams.
SLOPE (red.) / 1000 at cracking and ultimate load

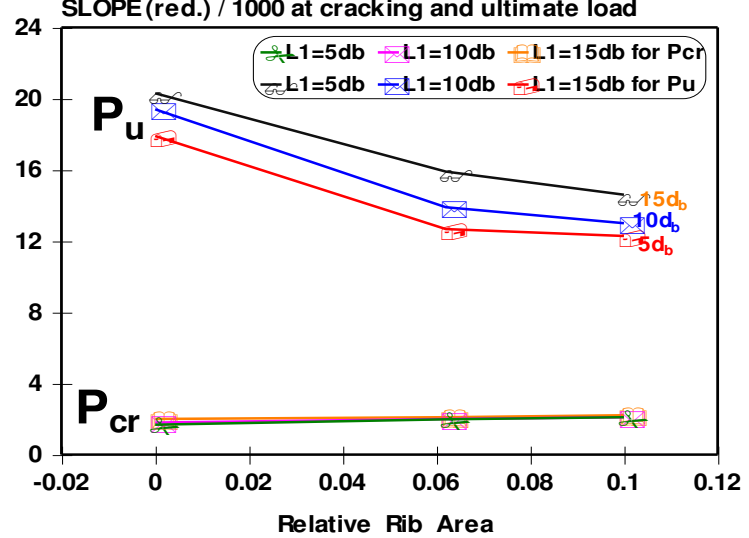

Fig. (18):Slope at cracking and ultimate load versus relative rib area of steel bar for tested beams 


\section{SUMMARY AND CONCLUSIONS}

(1) The final mode of failure for high-performance concrete (HPC) beams was bond failure for tested beams with smooth bars $\left(\propto_{\mathrm{sb}}=0.00\right)$. For the beams with steel bars having relative rib areas $\left(\propto_{\mathrm{sb}}=0.062 \& 0.10\right)$ and bonded part $\left(\mathrm{L}_{1}\right)=5 \mathrm{~d}_{\mathrm{b}}$ were flexural-bond failure. Also for $\left(\propto_{\mathrm{sb}}=0.062\right)$ and bonded part $\left(\mathrm{L}_{1}\right)=10 \mathrm{~d}_{\mathrm{b}}$. But were flexural failure for the beams with steel bars having relative rib areas $\left(\propto_{\mathrm{sb}}=0.062 \& 0.10\right)$ and bonded part $\left(\mathrm{L}_{1}\right)=15 \mathrm{~d}_{\mathrm{b}}$. Also for $\left(\propto_{\mathrm{sb}}=0.10\right)$ and bonded part $\left(\mathrm{L}_{1}\right)=10 \mathrm{~d}_{\mathrm{b}}$. The final mode of failure depend on the bonded part $\left(\mathrm{L}_{1}\right)$ and the rib geometry $\left(\propto_{\mathrm{sb}}\right)$ for the steel bar for the tested beams.

(2) The first of cracking load was early observed at small values of relative rib areas $\left(\propto_{\mathrm{sb}}\right)$ and bonded part $\left(\mathrm{L}_{1}\right)$ for the tested beams.

(3) The width of cracks and spacing between it were significantly increased with the decrease of both relative rib areas $\left(\propto_{\mathrm{sb}}\right)$ and bonded part $\left(\mathrm{L}_{1}\right)$ for the tested beams.

(4) The major cracks were formed at the max. Moment for all tested beams.

(5) For increase the relative rib areas $\left(\propto_{\mathrm{sb}}\right)$ increases the cracking and the ultimate load .The concrete strain at cracking and the ultimate load increases. Also the deflection and slope increases, but the slip at the cracking and the ultimate load decrease.

(6) The loads and concrete strain, deflection and slope increase but the slip decreases for increases the bonded parts $\left(\mathrm{L}_{1}\right)$.

(7) Increasing the relative rib areas $\left(\propto_{\mathrm{sb}}\right)$ from 0.0 to 0.062 increases the cracking and the ultimate load by about $48 \%$ and $62.3 \%$ respectively. Also for increasing the relative rib areas $\left(\propto_{\mathrm{sb}}\right)$ from 0.062 to 0.10 increases the cracking and the ultimate load by about $9 \%$ and $11.75 \%$ respectively.

(8) Increasing the bonded parts $\left(\mathrm{L}_{1}\right)$ from $5 \mathrm{~d}_{\mathrm{b}}$ to $10 \mathrm{~d}_{\mathrm{b}}$ increases the cracking and the ultimate load by about $12.13 \%$ and $12.2 \%$ respectively .Also for increasing the bonded parts $\left(\mathrm{L}_{1}\right)$ from $10 \mathrm{~d}_{\mathrm{b}}$ to $15 \mathrm{~d}_{\mathrm{b}}$ increases the cracking and the ultimate load by about $15 \%$ and $11.1 \%$ respectively

(9) The experimental to theoretical values of the cracking load were less than 1.0 for $\left(\propto_{\mathrm{sb}}=0.0\right.$, ) but range from 1.05 to 1.31 for $\left(\propto_{\mathrm{sb}}<0.062\right)$, and range from 1.13 to 1.44 for $\left(\propto_{\mathrm{sb}}>0.062\right)$

(10) The experimental to theoretical values of the ultimate load were less than 1.0 for beams with bonded part $\leq 10 \mathrm{~d}_{\mathrm{b}}$ and all relative rib areas, but more than 1.0 for beams with bonded part $>10 \mathrm{~d}_{\mathrm{b}}$ and all relative rib areas except for beam with smooth bars with relative rib area equal to zero

(11) The experimental to theoretical values of the deflections at cracking load were more than 1.0 except for beams with high relative rib area were less than 1.0.

(12) The experimental to theoretical values of the deflections at ultimate load were more than 1.0 for all tested beams.

\section{REFERENCES}

(1) $\mathrm{CEB} / \mathrm{FIP}$ model code for concrete structures-(CEB-FIP International Recommendations 3rd Edition, 1978).Paris. 
(2) S. Lee, T. Fujita, Kitayama, and S. Otani. 1991. Anchorage of Beam Reinforcement in High-Strength Reinforced Concrete Interior Beam-Column Joints. Transactions of the Japan Concrete Institute, Vol. 13, pp. 625-632.

(3) F. de Larrard, I. Schaller, and J. Fuchs. 1993. Effect of Bar Diameter on the Bond Strength of Passive Reinforcement in High-Performance Concrete. ACI Materials Journal, Jul-Aug, Vol. 90, No. 4, pp. 333-

(4) K. Kitayama, M. Fukuoka, K. Eto, and T. Fujita. 1991. Basic Tests on Bond Along High-Strength Beam Longitudinal Bars through High-Strength R/C Beam-Column Joint. Transactions of the Japan Concrete Institute, Vol. 13, pp. 619-624.

(5) T. Kaku, M. Yamada, S. lizuka, and J. Zhang. 1992. A Proposal of Bond Strength Equation for R. C. Members Including High Strength Concrete Level.

(6) Rehm' G, Eligehausen and Neubert,B.Erlauterung der Bewehrungsrichtlinien (Rationale for the detailing provisions of DIN 1045) Deutscher Ausschuss Fur Stahlbeton, Heft 300,1979.

(7) Ali M. Abdallah "Effect of rib geometry for steel reinforcements on bond characteristics and rotational capacity of exterior joints in structures" M.sc. Thesis. Assiut University, 2000.

(8) ACI Committee 318. 1995. Building Code Requirements for Reinforced Concrete. American Concrete Institute, Farmington Hills, Mich, 369 pp.

\section{سلوك الكمرات الخرسانة عالية المقاومة متأثرة بطول الرياط وهندسية النتوءات لأسياخ حليد التسليح الرئيسي}

في الآونة الأخيرة ظهرت الحاجة الماسة لاستخدام الخرسانة ذات المقاومة العالية و لذا أصبح من

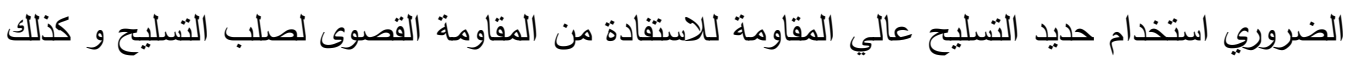

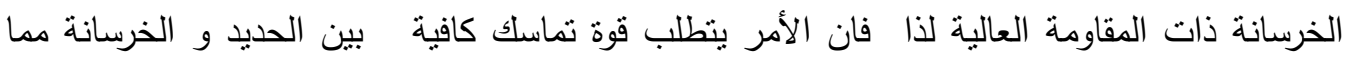

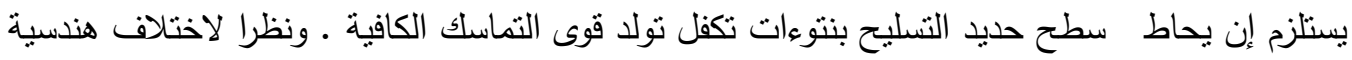
النتوءات لأنواع حديد التسليح المختلفة فقد ظهرت الحاجة لمعرفة اثر هذا الاختلاف علي سلوك الكمرات الخرسانة عالية المقاومة وذلك لأطوال مختلفة لطول الرباط.

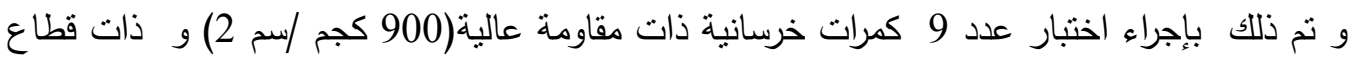

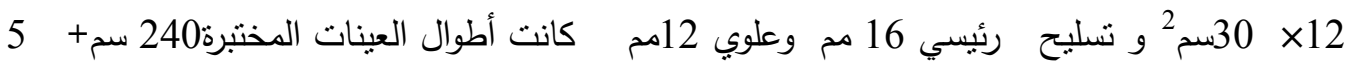
و 10و 15 مر ة قطر السيخ و قد نم الآخذ في الاعتبار العوامل الثالية :

1- طول التماسك لأسياخ الحديد المستخدم في عينات الاختبار خارج الدعامة و هي 5 ـ 15.10 مرات

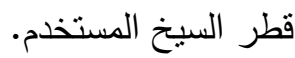


2- هندسية النتؤات والمساحة النسبية للنتؤ لحديد التسليح المستخدم في عينات الاختبار وقيمها هي .0.10.0.062-0.0)

3. تم استخدام رنبة واحدة من الخرسانة عالية المقاومة و كانت قيمتها هي (900 كجم/سم²) .

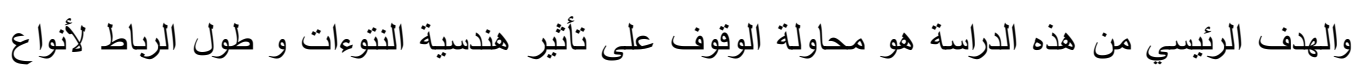

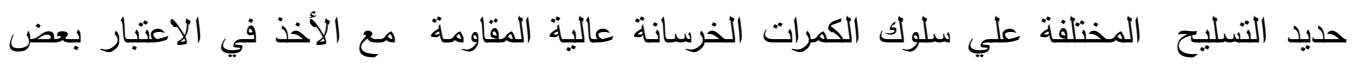

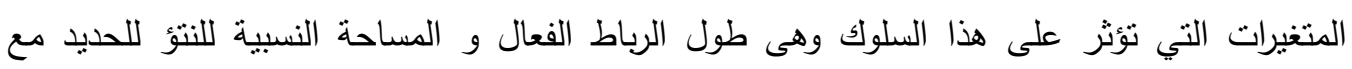
الخرسانة.

وقد نم التوصل لنتائج هامة في هذا البحث منها ما يلي :

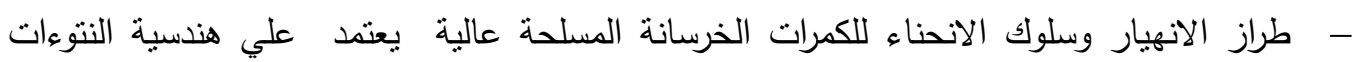

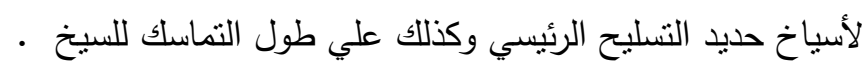

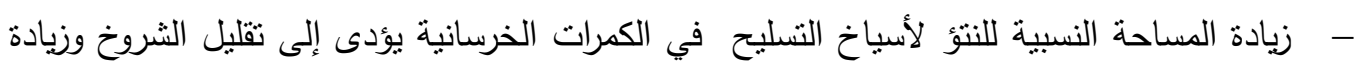

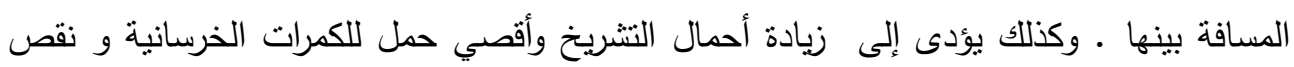

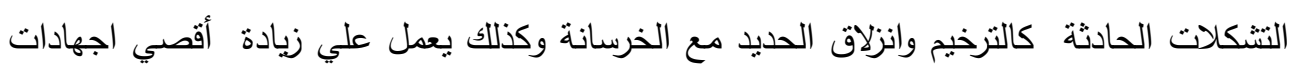
تماسك بين الحديد والخرسانة. - - زيادة طول التماسلك لاسياخ التسليح في الكمرات الخرسانية يؤدى إلى تقليل الثروخ وزيادة المسافة

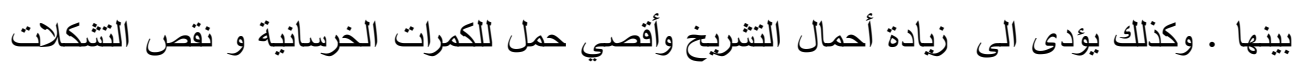

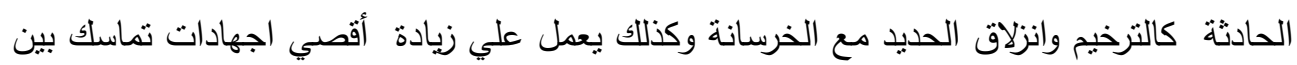

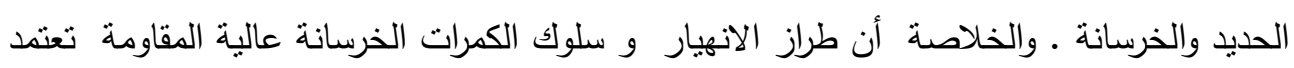

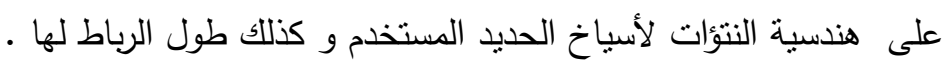

